\title{
A case report of polymyalgia rheumatica
}

\author{
Iryna Kniazkova ${ }^{1}$, Larysa Shapovalova², Maryna Bogun ${ }^{1}$
}

${ }^{1}$ Kharkiv National Medical University, Ukraine

${ }^{2}$ Kharkiv City Hospital No. 28, Ukraine

\begin{abstract}
The presented case report concerns a 62-year-old male patient who was admitted to the rheumatology department with a fever, shoulder and hip joint pain, significant limitation of movement in these joints and general weakness. Laboratory test revealed increase of inflammatory parameters, as ESR and C-reactive protein, rheumatoid factor and ACPA antibodies were absent. In the course of diagnostics, infections and cancer were excluded. The patient met the classification criteria for polymyalgia rheumatica. Polymyalgia rheumatica is not a rare disease, but the number of elderly people in the world continues to increase, and we can assume that the prevalence of this disease will increase in the coming years. At suspicion on polymyalgia rheumatica, it is necessary to exclude other rheumatic diseases, infections and malignant neoplasms. The authors also presented which diseases should be considered in the differential diagnosis.
\end{abstract}

Key words: differential diagnosis, polymyalgia rheumatica, classification criteria.

\section{Introduction}

The diagnostics of polymyalgia rheumatica (PMR) may be a difficult task, as a number of clinical and laboratory signs may also be observed in other pathologies, including other rheumatic diseases, infections (osteomyelitis, tuberculosis, bacterial endocarditis, etc.) and malignant neoplasms. In addition, the response to standard therapy may vary, and although a good response to the initial dose of glucocorticoids is expected, as many as 29-45\% do not respond to therapy in the first 4 weeks of treatment.

We present a clinical case of polymyalgia rheumatica.

\section{Case report}

A 62-year-old patient was admitted to the rheumatology department with the following complaints: temperature increase up to $38.6^{\circ} \mathrm{C}$, joint and upper limb pain, movement restriction, general weakness, and sleep disturbances due to the severity of pain.

From the anamnesis of the disease it is known that the patient fell ill unexpectedly 2 weeks ago after stress.
The patient was treated with diclofenac gel with an insignificant effect.

Data of objective examination on admission: the general condition of moderate severity was due to the joint status. Tenderness on palpation of shoulder joints and shoulder muscles was found; the patient could hardly lift her hands to the horizontal level, and could not move them behind her head.

Additionally, in physical examination the respiratory rate was $20 / \mathrm{min}$. There were no abnormalities in the lungs or auscultation. The boundaries of relative cardiac dullness were not expanded, the heart showed rhythmic activity, weakened I tone at the top and heart rate 96 bpm, with blood pressure 140/90 mm Hg. There were no pathological features in the abdominal examination and also there were no abnormalities in passing urine or stool.

Laboratory tests revealed: erythrocytes $4.4 \times 10^{12} / \mathrm{I}$, hemoglobin 128 and $144 \mathrm{~g} / \mathrm{l}$, color index 0.87 and 0.9 , leukocytes $7.8 \times 10^{9} / 1$ and $6.7 \times 10^{9} /$, eosinophils $4 \%$, basal cells $2 \%$, segmented $54 \%$, lymphocytes $36 \%$, monocytes $4 \%$, elevated ESR 50 and $30 \mathrm{~mm} / \mathrm{h}$, C-reactive protein $24 \mathrm{mg} / \mathrm{l}$ (normal range is up to 6), rheumatoid factor

Address for correspondence:

Iryna Kniazkova, Kharkiv National Medical University, Nauky Ave, 4, Kharkiv, Ukraine, e-mail: iknyazkova@ukr.net

Submitted: 9.02.2018; Accepted: 16.05.2018 
$12 \mathrm{lU} / \mathrm{ml}$ (normal range is up to 14), total protein $76 \mathrm{~g} / \mathrm{l}$, sialic acids $3.18 \mathrm{mmol} / \mathrm{l}$ (normal range is $1.8-2.7 \mathrm{mmol} / \mathrm{l}$ ), glucose $3.8 \mathrm{mmol} / \mathrm{l}$, aspartate aminotransferase $47 \mathrm{U} / \mathrm{l}$, alanine aminotransferase $39 \mathrm{U} / \mathrm{l}$, total cholesterol 5.2 $\mathrm{mmol} / \mathrm{l}$, urea $4.4 \mathrm{mmol} / \mathrm{l}$, creatinine $0.064 \mathrm{mmol} / \mathrm{l}$, creatine phosphokinase $113.0 \mathrm{U} / \mathrm{l}$ (normal range is 26-192), in urinalysis without significant abnormalities, anti-cyclic citrullinated peptide antibodies (ACPA) $<7 \mathrm{U} / \mathrm{ml}$ (normal range is up to 17.0), negative antibody results for anti-neutrophil cytoplasmic antibody (ANCA) screening (myeloperoxidase - MPO), proteinase-3 (PR-3), and also negative test for detection of basal membrane of the glomerular apparatus (GBM).

Electrocardiography (ECG) values: sinus rhythm is accelerated, heart rate - 104 per minute, hypertrophy of the left ventricle. In the dynamics of treatment - heart rate is 72 per minute.

In the radiological examination of the shoulders: no pathology was detected. Echocardiography revealed: initial signs of atherosclerotic aortocardiosclerosis, ejection fraction (EF) 62\%. In the abdominal ultrasonography no pathological findings in the liver, gallbladder, pancreas, spleen, kidneys. The esophagogastroduodenoscopy with biopsy, colonoscopy and computed tomography of lungs also were performed with no abnormalities pointing to oncological diseases.

Taking into account complaints, analysis of the disease, and all results the final diagnosis of polymyalgia rheumatica was established with third stage activity, with joint and upper limb injuries, and functional insufficiency of stages $\|-\| I$.

Treatment with methylprednisolone from $16 \mathrm{mg} /$ day, pantoprazole, ossein-hydroxyapatite compound (Osteogenone) and diclofenac was introduced. On treatment, pain in muscles and joints decreased, but did not resolve, the range of movements increased and the activity of the inflammatory process in laboratory tests decreased. The patient was discharged in a satisfactory condition. It was recommended to visit a rheumatologist at the place of residence in 7-10 days after discharge from the hospital to undergo regular medical check-up and for further therapy correction.

Gradual reduction of the dosage of methylprednisolone by $1 \mathrm{mg}$ in 7-10 days under control of clinical and laboratory indicators until complete withdrawal is recommended in a month.

\section{Discussion}

Although the described case does not differ from the classic PMR descriptions, it draws attention to several aspects when making a diagnosis of PMR.

Most doctors are familiar with the main characteristics of PMR pain in the proximal parts of limbs and morning stiffness, accompanied by a significant increase of acute phase parameters. However, the reference to clinical manifestations only may lead to diagnostic errors. Thus, proximal pain and morning stiffness are observed

Table I. Classification criteria for polymyalgia rheumatica (European League Against Rheumatism - EULAR) [5]

\begin{tabular}{|c|c|c|}
\hline \multicolumn{3}{|c|}{$\begin{array}{l}\text { Required criteria: } \\
\text { age } 50 \text { years and over } \\
\text { bilateral gnawing pain in the region of the shoulder girdle } \\
\text { increased levels of C-reactive protein (CRP) and/or ESR }\end{array}$} \\
\hline Criterion & $\begin{array}{l}\text { Scoring with the absence } \\
\text { of ultrasound data } \\
\text { (0-6 points) }\end{array}$ & $\begin{array}{l}\text { Scoring with the } \\
\text { presence of ultrasound } \\
\text { data ( } 0-8 \text { points) }\end{array}$ \\
\hline Morning stiffness for more than $45 \mathrm{~min}$ & 2 & 2 \\
\hline Pain in the region of hip joints or restriction of their movement & 1 & 1 \\
\hline $\begin{array}{l}\text { Absence of rheumatoid factor and anti-cyclic citrullinated peptide } \\
\text { antibodies (ACPA) }\end{array}$ & 2 & 2 \\
\hline Absence of other joint damage & 1 & 1 \\
\hline $\begin{array}{l}\text { Presence of at least one-sided subdeltoid bursitis and/or tenosynovi- } \\
\text { tis of the biceps, and/or synovitis of the shoulder joint (posterior } \\
\text { or axillary region) and at least one-sided hip synovitis, and/or } \\
\text { trochanteric bursitis }\end{array}$ & - & 1 \\
\hline $\begin{array}{l}\text { Presence of bilateral subdeltoid bursitis, tenosynovitis of the biceps } \\
\text { or synovitis of the shoulder joints }\end{array}$ & - & 1 \\
\hline $\begin{array}{l}\text { To confirm the diagnosis of polymyalgia rheumatica: } \\
\text { in patients meeting the mandatory criteria and without ultrasonic da } \\
\text { in patients meeting the mandatory criteria and with ultrasonic data, }\end{array}$ & $\begin{array}{l}4 \text { points should be reached } \\
\text { oints should be reached }\end{array}$ & \\
\hline
\end{tabular}


Table II. Diseases with which a differential diagnostics of polymyalgia rheumatica is made

\begin{tabular}{|c|c|}
\hline Rheumatic diseases & Clinical signs \\
\hline Rheumatoid arthritis & $\begin{array}{l}\text { Articular syndrome with the involvement of joints of the hands } \\
\text { (metacarpophalangeal II and III and proximal interphalangeal), } \\
\text { metatarsophalangeal, knee, wrist, ankle joints; positive results } \\
\text { of rheumatoid factor, anti-citrulline antibodies, in particular, } \\
\text { anti-cyclic citrullinated peptide antibodies (ACPA) and others, } \\
\text { radiographic findings (erosive arthritis, periarticular osteoporosis) }\end{array}$ \\
\hline $\begin{array}{l}\text { Delayed spondyloarthropathies, including ankylosing } \\
\text { spondylitis, psoriatic arthritis }\end{array}$ & $\begin{array}{l}\text { Pain in the lumbar region and morning stiffness; articular syndrome } \\
\text { (possible damage of large, interphalangeal joints of hands); } \\
\text { radiographic findings of sacroiliitis; psoriasis }\end{array}$ \\
\hline $\begin{array}{l}\text { Remitting seronegative symmetrical synovitis with } \\
\text { pitting edema, abbreviated RS3PE syndrome }\end{array}$ & $\begin{array}{l}\text { Symmetric multiple synovitis, seronegative in rheumatoid factor, } \\
\text { evident bilateral soft edema of hands and feet }\end{array}$ \\
\hline $\begin{array}{l}\text { Systemic lupus erythematosus, scleroderma, } \\
\text { Sjögren's syndrome, vasculitis }\end{array}$ & $\begin{array}{l}\text { Fatigue, morning stiffness in joints, systemic autoimmune disease, } \\
\text { presence of antinuclear antibodies and antineutrophil cytoplasmic } \\
\text { antibodies }\end{array}$ \\
\hline $\begin{array}{l}\text { Idiopathic inflammatory myopathies } \\
\text { (dermatomyositis, polymyositis) }\end{array}$ & $\begin{array}{l}\text { Progressive weakness in the proximal muscles of arms and legs, skin } \\
\text { rashes, increased creatine kinase in the blood }\end{array}$ \\
\hline \multicolumn{2}{|l|}{ Non-inflammatory pathology } \\
\hline Osteoarthrosis, deforming spondylosis & $\begin{array}{l}\text { Pain in the shoulder joint, in the neck and hip joints; degenerative } \\
\text { changes on X-ray image }\end{array}$ \\
\hline $\begin{array}{l}\text { Scapulohumeral periarthritis, adhesive capsulitis } \\
\text { ("frozen shoulder") }\end{array}$ & $\begin{array}{l}\text { Periarticular pain, restriction of movements; ultrasound and magnetic } \\
\text { resonance imaging allow one to diagnose the specific inflammation } \\
\text { of the joint (synovial) bag }\end{array}$ \\
\hline $\begin{array}{l}\text { Infections, including viral syndromes, osteomyelitis, } \\
\text { bacterial endocarditis, tuberculosis }\end{array}$ & $\begin{array}{l}\text { Fever, weight loss, heart murmurs, bone and soft tissue pains, } \\
\text { microscopic hematuria }\end{array}$ \\
\hline Chronic pain syndromes, fibromyalgia, depression & $\begin{array}{l}\text { Fatigue, long-term pain, some painful regions (muscles, etc.), feeling of } \\
\text { sadness, decrease or loss of usual interests }\end{array}$ \\
\hline $\begin{array}{l}\text { Endocrine and metabolic diseases, in particular, the } \\
\text { pathology of the thyroid and parathyroid glands and } \\
\text { osteomalacia }\end{array}$ & $\begin{array}{l}\text { Pain in bones, fatigue; changes of the content of thyroid and } \\
\text { parathyroid hormones, the concentration of calcium, phosphorus, } \\
\text { vitamin D }\end{array}$ \\
\hline
\end{tabular}

in many other diseases. A third of patients show systemic manifestations (fever, loss of appetite and weight loss) [1]. In addition, 15-30\% of patients experience pain in the distal parts of the musculoskeletal system. What is important, the beginning may be sudden, as occurred in the described patient, while the long course and poor response to treatment may suggest other diagnoses.

It is known that giant cell arteritis is associated with polymyalgia rheumatica. It was established that 10-15\% of patients with polymyalgia rheumatica will subsequently develop giant cell arteritis. In these conditions, polymyalgia rheumatica is revealed in $50 \%$ of patients with giant cell arteritis [1, 2]. In addition, a significant increase in laboratory parameters of inflammation may occur in other pathologies, in particular rheumatic diseases, malignancy and infections. Family history of PMR is very rare, but it is also described [3].

A number of clinicians from experience administer corticosteroids as a diagnostic test, and the results are used as the main differential sign of PMR. Such an approach may lead to misdiagnosis because administration of corticosteroids with pronounced anti-inflammatory properties may conceal the symptoms of many severe pathological conditions which include inflammatory and non-inflammatory rheumatic diseases, e.g. osteoarthritis, rheumatoid arthritis, and infections and malignant tumors, especially with long-term therapy and at high dosages.

It should be noted that pain and stiffness of the muscles of the shoulder girdle are observed in 70-95\% of patients with PMR [4].

Classification criteria for identifying polymyalgia rheumatica as a nosological form are presented in Table I [5].

Clinical evidence suggests that in some cases, an initial diagnosis requires revision in future. The main pathological conditions with which a differential diagnosis of polymyalgia rheumatica should be made are presented in Table II.

It is important to exclude active infection, malignant neoplasms and other inflammatory diseases. We should 
particularly focus on the need to exclude acute or active infection, oncological pathology and other inflammatory diseases. In addition, symptoms similar to polymyalgia rheumatica may be found in the onset of rheumatoid arthritis. Anti-cyclic citrullinated peptide antibodies are the most diagnostically effective marker of rheumatoid arthritis [6], and are included in the European League Against Rheumatism (EULAR)/American College of Rheumatology (ACR) RA classification criteria and allow one to differentiate rheumatoid arthritis and PMR.

\section{Conclusions}

Polymyalgia rheumatica is not a rare disease. As the number of elderly people in the world continues to increase, the prevalence of this disease will still increase in the coming years. Upon suspicion of PMR, it is necessary to exclude other rheumatic diseases, infections (osteomyelitis, tuberculosis, bacterial endocarditis, etc.) and malignant neoplasms, especially in the group of patients at a very advanced age, with family history of cancer, with contact with infection or patients from endemic areas for specific infections.

Knowledge of the directions of diagnostic search is extremely important for the doctors of different spe- cialties since early diagnosis of PMR and further proper management of patients allow one to significantly improve the patient's prognosis.

The authors declare no conflict of interest.

\section{References}

1. Dasgupta B, Borg FA, Hassan N, et al. BSR and BHPR guidelines for the management of giant cell arteritis. Rheumatology (Oxford) 2010; 49: 1594-1597.

2. Bhaskar D. Concise guidance: diagnosis and management of polymyalgia rheumatica. Clin Med 2010; 10: 270-274.

3. Liozon E, Ouattara B, Rhaiem K, et al. Familial aggregation in giant cell arteritis and polymyalgia rheumatica: a comprehensive literature review including 4 new families. Clin Exp Rheumatol 2009; 27 (Suppl. 52): S89-94.

4. Muratore F, Pazzola G, Pipitone N, et al. Recent advances in the diagnosis and treatment of polymyalgia rheumatic. Exp Rev Clin Immunol 2016; 12: 1037-1045.

5. Macchioni P, Boiardi L, Catanoso M, et al. Performance of the new 2012 EULAR/ACR classification criteria for polymyalgia rheumatica: comparison with the previous criteria in a single-centre study. Ann Rheum Dis 2014; 73: 1190-1193.

6. Buttgereit F, Dejaco C, Matteson EL, et al. Polymyalgia Rheumatica and Giant Cell Arteritis: A Systematic Review. JAMA 2016; 315: 2442-2458 